\title{
Polymer fume fever
}

\author{
Taro Shimizu, Osamu Hamada, Akinori Sasaki, Mari Ikeda
}

Nerima Hikarigaoka Hospital, Tokyo, Japan

\section{Correspondence to} Dr Taro Shimizu, shimizutaro7@gmail.com
To cite: Shimizu T, Hamada O, Sasaki A, et al. BMJ Case Reports Published online: 10 December 2012 doi:10.1136/bcr-2012007790

\section{SUMMARY}

A 29-year-old Japanese man presented with fever, dyspnoea and non-productive cough after massive inhalation of evaporant from a polytetrafluoroethylenecoated cooking pan. Chest CT scan showed diffuse interstitial infiltration in both lungs. Based on the patient history, images and the pan he brought to the hospital, polymer fume fever was strongly suspected. His symptoms dramatically improved over the following 2 days after admission.

\section{BACKGROUND}

Polymer fume fever is a relatively rare disease, caused by inhalation of products of thermal degradation of polytetrafluoroethylene (PTFE). Clinical manifestations are typically characterised by constitutional symptoms such as fever, shivering, sore throat and weakness. We believe that knowledge of this disease as one of the environment or occupation-related diseases is very important because better understanding of this condition enables clinicians to make the diagnosis correctly, educate patients properly and ultimately realise a better outcome of the patients.

\section{CASE PRESENTATION}

A previously healthy 29-year-old Japanese man presented with fever, dyspnoea and non-productive cough. He was well several hours prior to admission. On the day of admission, he prepared lunch by around 11:00. While he was waiting for boiling water for pasta, he took a nap without turning off the fire.

When he got up around 16:00, which was $5 \mathrm{~h}$ after he fell asleep, he noticed his room filled with white smoke. He thought that the smoke was due to the pan on the fire which was not turned off, and he turned the fire off immediately. He brought the burned pan to the sink and put the pan under running water from the faucet of the kitchen. As soon as the running water hit the pan, an explosive vapor came out from the surface of the pan. He accidentally inhaled the vapour. Several hours after that, he gradually felt fatigue and dyspnoeic. He became anxious and called emergency medical service.

He denied chest pain, nausea, vomiting or diarrhoea. He was not on any medication and was not allergic to any drug or food. He brought the cooking pan with him, and the coating of the centre of the pan was burnt (figure 1).

\section{INVESTIGATIONS}

On examination, he was alert and not in acute distress. Respiratory rate was $24 / \mathrm{min}$ with $\mathrm{SpO}_{2}$ of $94 \%$ on ambient air, temperature was $38^{\circ} \mathrm{C}$, pulse was 88 beats/min and blood pressure was 124/ $75 \mathrm{~mm} \mathrm{Hg}$. Lung sounds showed diffuse fine crackles bilaterally. Heart sound was normal. Chest CT scan revealed diffuse interstitial infiltration in both lungs (figure 2).

\section{TREATMENT}

On the basis of the patient history, images and the pan he brought to the hospital, polymer fume fever was strongly suspected. He was treated with oxygen inhalation under close observation. On the following day, his symptoms including cough, dyspnoea and fever dramatically diminished and completely disappeared on the third day of admission.

\section{DISCUSSION}

We speculated that the symptoms of this patient were triggered by the products of thermal degradation of PTFE that were present in the fumes from the cooking pan.

PTFE is widely used in household goods such as coatings for cooking pans and spray. ${ }^{1}$ Although PTFE is extremely inert as to physiological action, its decomposition of pyrolysis, more than from 315

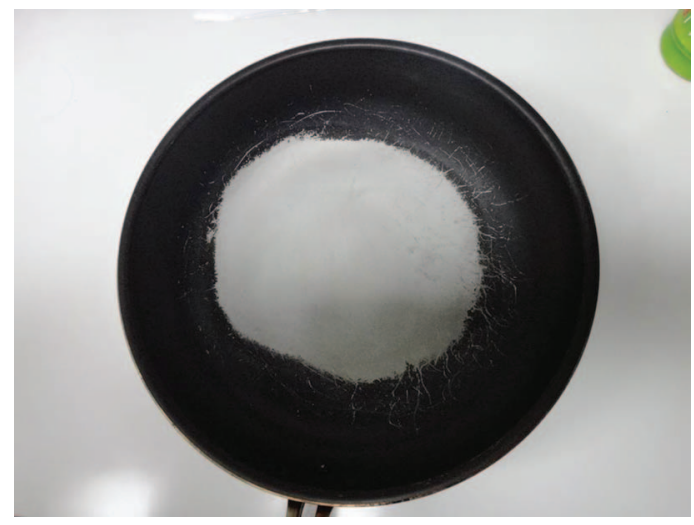

Figure 1 The coating of the centre of the pan was burned off.

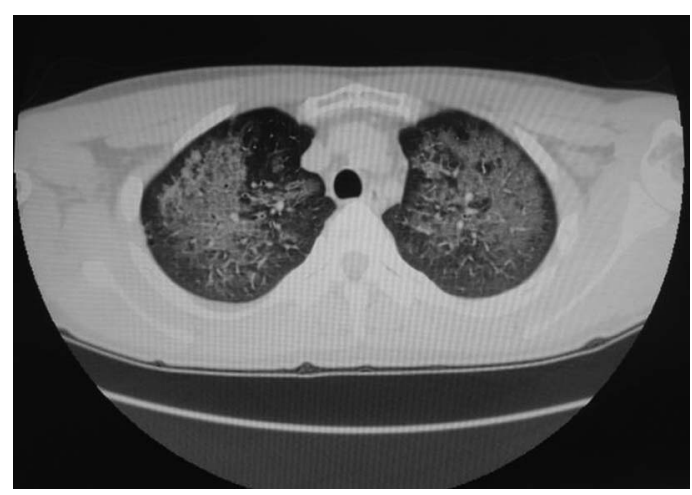

Figure 2 CT scan of the chest showed diffuse interstitial infiltration in both lungs. 
to 375 , can cause rapid and self-limiting influenza-like symptoms when the products are inhaled. ${ }^{1}{ }^{2}$ Constitutional signs and symptoms, characterised by fever, shivering, sore throat and dyspnoea, are the cardinal signs of the disease, which present several hours after exposure. Due to the similarities of symptoms to viral infection, polymer fume fever sometimes leads physicians to a misdiagnosis of viral 'flu'. ${ }^{3}$ Since first being described in 1951, polymer fume fever has been reported to show varied clinical presentations, ranging from influenza-like symptoms to severe toxic effects such as pulmonary oedema, pneumonitis and death, while its degree of severity depends on the specific conditions of exposure. ${ }^{3-6}$ When higher temperatures and/or longer durations of exposure are involved, significant pulmonary involvement, including radiographic consolidation, is a potential complication. ${ }^{2} 6$

As seen in our patient, improvement of the symptoms was very rapid despite diffuse bilateral lung infiltration.
Competing interests None.

Patient consent Obtained.

\section{REFERENCES}

1 Patel MM, Miller MA, Chomchai S. Polymer fume fever after use of a household product. S Am J Emerg Med 2006;24:880-1.

2 Kuntz WD, McCord CP. Polymer-fume fever. J Occup Med 1974;16:480-2.

3 Silver MJ, Young DK. Acute noncardiogenic pulmonary edema due to polymer fume fever. Cleve Clin I Med 1993;60:479-82.

4 Harris DK. Polymer-fume fever. Lancet 1951;2:1008-11.

5 Shusterman DJ. Polymer fume fever and other fluorocarbon pyrolysis-related syndromes. Occup Med 1993;8:519-31.

6 Williams N, Atkinson W, Patchefsky AS. Polymer-fume fever not so benign. J Occup Med 1974;16:519-22.

\section{Learning points}

- Polymer fume fever is caused by inhalation of the products of pyrolysis of polytetrafluoroethylene.

- Misdiagnosis usually occurs because the symptoms resemble influenza virus infection.

- In another word, in patients with flu like symptoms, polymer fume fever should be ruled out until proven otherwise.

Copyright 2012 BMJ Publishing Group. All rights reserved. For permission to reuse any of this content visit

http://group.bmj.com/group/rights-licensing/permissions.

BMJ Case Report Fellows may re-use this article for personal use and teaching without any further permission.

Become a Fellow of BMJ Case Reports today and you can:

- Submit as many cases as you like

- Enjoy fast sympathetic peer review and rapid publication of accepted articles

- Access all the published articles

- Re-use any of the published material for personal use and teaching without further permission

For information on Institutional Fellowships contact consortiasales@bmjgroup.com

Visit casereports.bmj.com for more articles like this and to become a Fellow 